\title{
IMPROVING STUDENTS'ACHIEVEMENT IN READING NARRATIVE TEXT BY USING RECIPROCAL TEACHING METHOD
}

\author{
*Ruth Adelina Sianturi \\ **Sumarsih
}

\begin{abstract}
This study deals with the improving students' achievement in reading narrative text by using reciprocal teaching. The research of this study was conducted by using action research. The subject of this study was the tenth grade students SMA Negeri 6 Medan. One class was taken as the subject, namely the students from X-5. There were 49 students, consisting of 22 male and 27 female. This research was done in two cycles; there was three meetings in cycle I and three meetings in cycle II. The instruments for collecting data were reading narrative text (25 items of multiple choice tests) teacher make test as quantitative data and interview sheet, observation sheet and diary notes as qualitative data. In analyzing the data, the mean of the students' score for the treatment I was 61.79 , for the treatment II was 72.24 and treatment III was 81.71 . The data showed that the students' score was rising in every treatment. The conclusion is that the use of reciprocal teaching method can improve students' reading comprehension in narrative text. It suggested to English teacher to apply reciprocal teaching method in teaching reading comprehension.
\end{abstract}

Key words: reading, narrative text, reciprocal teaching.

\footnotetext{
* A graduate of English Language and Literature Department of UNIMED

** A lecturer of English Language and Literature Department of UNIMED
} 


\section{INTRODUCTION}

\section{Background of the Study}

Reading is one of the four language skills that is important to achieve to show that one is able in learning a language. Since reading is an activity to draw meaning or take information from printed or written text, one who does reading activity is expected to know better after reading. In fact, many students are still having problems with reading. As a proof, when the researcher did a Teacher Training Practice (PPLT 2011), there were students who were not interested in reading, they were unable to find the meaning of what they read and they did reading when they had homework only. These students' failure may be not only caused by the students' lack of knowledge to comprehend the text, but also caused by the teacher's strategy in teaching.

Further, in English Curriculum, Educational Unit-Oriented Curriculum (Kurikulum Tingkat Satuan Pendidikan, KTSP) of Senior High School level states that there are four language skills that should be achieved in learning process namely, listening, speaking, reading and writing. Reading is one of the four skills that must be mastered. It is stated that the students are intended to comprehend the text. In grade tenth of Senior High School, the several kinds of text genre are reports, narrative, analytical expositions.

Improving students' reading comprehension is not an easy task. Teaching reading nowadays is directly faced to some problems above. Reading comprehension centers on the ability to derive meaning from what is read. Without comprehension, a student does not really read. It is the teacher's responsibility to help the students to comprehend the text. Teacher needs to assess students' reading needs. Teacher should design and redesign courses in order to make an interesting learning process for students.

Reciprocal teaching method offers a way to help students to be active and easier to interpret meaning or information in reading. This method benefits both the teacher and the students. Reciprocal teaching method enables students to comprehend the text with or without the teacher, then for teacher reciprocal teaching helps him/her design an interesting teaching process. 
Based on the explanation above, the writer is interested to conduct a research which is entitled 'Improving students' achievement in reading skill by using reciprocal teaching method". In this research, the writer wants to know, how far the reciprocal teaching can improve the students' achievement in reading.

\section{Research Question}

Based on the background of the study, the problem of the study proposed as the following "Is the use of reciprocal teaching method significantly improve the students' reading skill?"

\section{The Objective of the Study}

The objective of the study is to investigate whether the application of reciprocal teaching method can improve significantly students reading skill.

\section{The Scope of the Study}

Based on the Curriculum in Senior High School grade tenth, there are some types of text that must be taught, they are: reports, narrative, analytical expositions. But in this case, the research focuses on narrative text by using reciprocal teaching as method in teaching.

\section{The Significance of the Study}

The findings of this study are important and useful for:

a. The English teachers to improve their interest and ability in teaching reading by applying reciprocal teaching method

b. The students to improve their interest and comprehension in reading by practicing reciprocal teaching method

c. The researcher who wants to conduct a research related to this study. 


\section{Conceptual Framework}

Reading for comprehension, when accomplished by skilled readers requires very rapid and automatic processing of word, strong skill in informing a general meaning representation of main ideas and efficient coordination of many process under very limited times constraints. In reading process, the students as the reader should has a good grasped of how to understand the text easily, how to make a summary, and relate those to their background knowledge as appropriate. Therefore, the teacher should be able to conduct a suitable strategy to improve the students' ability reading comprehension.

The purpose of reciprocal teaching as general is to facilitate a group effort between teacher and students as well as among students in the task of bringing meaning to the text. The strategies chosen not only promote reading comprehension but also provide opportunities for students to learn to monitor their own learning and thinking. The structure of the dialogue and interactions of the group members require that all students participate and foster new relationships between students of different ability levels.

\section{METHODOLOGY}

This research was conducted using Classroom Action Research (CAR). The aim of CAR is to implement a certain instructional strategy in order to solve practical instructional problems in classrooms. It was done by the teacher in their own classrooms. The English teacher, should solve their classroom problems or improve the quality of their class practices to get a much better English achievement as a result of the learning process. The results of each cycle was used to determine whether to conduct the next cycle, until the problems is solved. The model cycle of CAR is presented in Figure 1. 


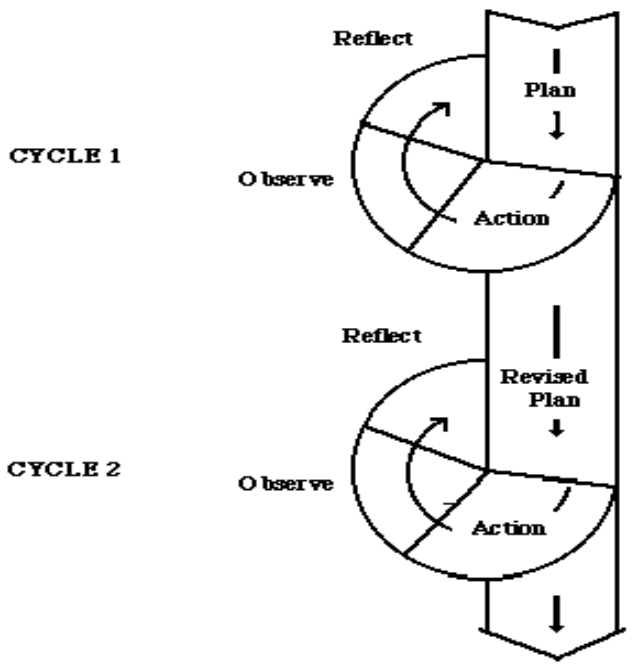

Figure 1.1

\section{Action Research Model}

\section{Instrument of Data Collection}

The instrument used: (1) reading tests, (2) interview sheet, (3) observation sheet and (4) diary notes.

\section{Reading Tests}

Reading tests in collecting the data, the writer were used multiple choice tests. The students were asked to answer 25 questions of multiple choice tests for 45 minutes.

\section{Interview Sheet}

Interview sheet was used to collect information about teacher, students' attitude, perception, point of view, and feeling learning English.

\section{Observation Sheet}

Based on the observation list, the researcher has good ability to opening the class. The researcher motivated the students in teaching learning process. The researcher provided the material clearly and systematically. The researcher could organize the classroom effectively. The researcher gave enough chance to the students to asking questions or giving comments. The researcher had good interaction with the 
students. The students paid attention to the teacher's explanation and instruction. The students also gave good response to the teacher. The students' interaction was good also in group discussion and felt interesting in using reciprocal teaching method. A complete analysis can be seen in Appendix D.

\section{Diary Notes}

Diary Notes were written for personal evaluation about the situation of the class while the teaching-learning process. Diary notes were written up by the researcher in every meeting during the research. It contained the researcher's personal evaluation of applying Reciprocal Teaching Method during the teaching-learning process.

\section{Procedure of the Data Collection}

This research was conducted by administering six meetings in two cycles. There were four steps in each cycle namely; (1) planning, (2) action, (3) observation, and (4) reflection. Each cycle was carried out in three meetings. So, there would be six meetings all together.

\section{Scoring of the Test}

In evaluating the students' reading achievement, the writer will use multiple choice tests. The writer administrated 25 items of multiple choice tests. In scoring the reading test, it is determined that the ranging from 0-100 by accounting the correct answer. The correct answer is will give 1 while the wrong answer is will give 0 and by applying this formula:

$$
\mathrm{S}=\frac{R}{N} \times 100 \%
$$

Where: $\quad S=$ Score number of the test

$\mathrm{R}=$ Number of the correct answer(s)

$\mathrm{N}=$ Number of the questions 


\section{Technique of Data Analysis}

The qualitative data are analyzed from the interview sheet, observation sheet and diary notes to describe the improvement of the students' achievement. The qualitative data is analyzed to know the students' problems in teaching learning process. The quantitative data are analyzed by computing the score of reading test.

To know the mean of the students' score for each cycle, the writer will apply the following formula:

$$
\bar{X}=\frac{\sum x}{N} \times 100 \%
$$

Where: $\quad \bar{X}=$ the mean of the students' score

$$
\begin{aligned}
& \sum x=\text { the total score } \\
& \mathrm{N}=\text { the number of the students }
\end{aligned}
$$

Next, to categorize the number of master students, the researcher continues it by applying the following formula:

$P=\frac{R}{T} \times 100 \%$

Where: $\quad P=$ the percentage of students who get the point 75

$R=$ the number of students who get the points up 75

$T=$ the total number of students who do the test

\section{RESULT AND DISCUSSION}

\section{Result}

The quantitative data was taken from the result of reading test which was carried out in two cycles. The improvement of students reading comprehension by using reciprocal teaching method can be seen from the orientation test, cycle I and cycle II as follows: 
Table 4.2 The Score of Orientation Test, Cycle I and Cycle II

\begin{tabular}{|c|c|c|c|c|}
\hline No & $\begin{array}{c}\text { Students' } \\
\text { Initial } \\
\end{array}$ & Orientation Test & Cycle I & Cycle II \\
\hline 1 & $\mathrm{AG}$ & 52 & 64 & 76 \\
\hline 2 & ASP & 60 & 70 & 76 \\
\hline 3 & $\mathrm{AJ}$ & 72 & 84 & 88 \\
\hline 4 & BHP & 60 & 64 & 76 \\
\hline 5 & $\overline{\mathrm{DS}}$ & 52 & 68 & 76 \\
\hline 6 & DRS & 56 & 64 & 76 \\
\hline 7 & DSB & 60 & 72 & 84 \\
\hline 8 & $\mathrm{DP}$ & 72 & 82 & 88 \\
\hline 9 & $\overline{\mathrm{DCM}}$ & 56 & 64 & 76 \\
\hline 10 & EW & 56 & 68 & 76 \\
\hline 11 & EDT & 60 & 72 & 84 \\
\hline 12 & LFS & 64 & 72 & 84 \\
\hline 13 & MS & 72 & 80 & 92 \\
\hline 14 & MFW & 52 & 64 & 76 \\
\hline 15 & PCR & 64 & 76 & 84 \\
\hline 16 & RHD & 68 & 76 & 80 \\
\hline 17 & $\mathrm{RD}$ & 56 & 72 & 80 \\
\hline 18 & RP & 56 & 72 & 80 \\
\hline 19 & RHS & 68 & 76 & 88 \\
\hline 20 & RSS & 52 & 64 & 76 \\
\hline 21 & RPS & 56 & 72 & 76 \\
\hline 22 & $\mathrm{RM}$ & 72 & 80 & 88 \\
\hline 23 & SM & 68 & 80 & 92 \\
\hline 24 & SFT & 72 & 80 & 92 \\
\hline 25 & SA & 56 & 64 & 76 \\
\hline 26 & TP & 52 & 68 & 76 \\
\hline 27 & WPP & 64 & 76 & 88 \\
\hline 28 & WL & 72 & 80 & 88 \\
\hline 29 & BKS & 56 & 64 & 76 \\
\hline 30 & DK & 68 & 76 & 84 \\
\hline 31 & FFP & 56 & 68 & 76 \\
\hline 32 & FSE & 60 & 76 & 84 \\
\hline 33 & $\mathrm{HN}$ & 56 & 64 & 76 \\
\hline 34 & $\mathrm{HS}$ & 64 & 72 & 80 \\
\hline 35 & IB & 52 & 64 & 76 \\
\hline 36 & $\mathrm{KS}$ & 68 & 80 & 88 \\
\hline 37 & LPP & 56 & 68 & 80 \\
\hline 38 & $\mathrm{LT}$ & 60 & 68 & 76 \\
\hline
\end{tabular}




\begin{tabular}{|l|c|c|c|c|}
\hline 39 & MRS & 72 & 76 & 92 \\
\hline 40 & NAS & 68 & 76 & 84 \\
\hline 41 & NS & 72 & 80 & 88 \\
\hline 42 & RLS & 68 & 76 & 84 \\
\hline 43 & RR & 56 & 64 & 76 \\
\hline 44 & SP & 72 & 80 & 92 \\
\hline 45 & WIS & 64 & 76 & 84 \\
\hline 46 & YL & 52 & 64 & 76 \\
\hline 47 & IP & 56 & 72 & 76 \\
\hline 48 & MH & 60 & 72 & 76 \\
\hline 49 & KAS & 72 & 80 & 88 \\
\hline & TOTAL & $\sum \mathbf{X}=\mathbf{3 0 2 8}$ & $\sum \mathbf{X = 3 5 4 0}$ & $\sum \mathbf{X}=\mathbf{4 0 0 4}$ \\
\hline & MEAN & $\mathbf{X = 6 1 . 7 9}$ & $\mathbf{X = 7 2 . 2 4}$ & $\mathbf{X}=\mathbf{8 1 . 7 1}$ \\
\hline
\end{tabular}

From the table above, it can be showed that:

a) The highest and the lowest score orientation test were 72 points and 52 points.

b) The highest and the lowest score cycle I were 80 points and 64 points.

c) The highest and the lowest score cycle II were 92 points and 76 points.

The improvement of students' score in reading comprehension could be seen from the mean of the students for each meeting by using this formula:

$$
\bar{X}=\frac{\sum x}{N} \times 100 \%
$$

Where: $\bar{X}=$ the mean of the students' score

$\sum x=$ the total score

$\mathrm{N}=$ the number of the students

In the orientation test, the number of the students was 49 and the total sore of the students was 3028 , so the mean was $X=\frac{3028}{49} \times 100 \%=61.79$. In the cycle I test, the number of the students was 49 and the total score of the students was 3540 , so the mean 
was $X=\frac{3540}{49} \times 100 \%=72.24$. In the cycle II test, the number of the students was 49 and total score of the students was 4004 , so the mean was $X=\frac{4004}{49} \times 100 \%=81.71$.

Further, in categorizing the number of master students, the writer used the following formula:

$$
P=\frac{R}{T} \times 100 \%
$$

Where: $P=$ percentage of students who get the point 75

$R=$ the number of students who get the points up 75

$T=$ the total number of student taking the test

In the orientation test, the number of the students who got the points 75 was nothing. The percentage of this was $P 1=\frac{0}{49} \times 100 \%=0 \%$. In the cycle I test, the number of the students who got the points 75 were 20 students. The percentage of this was $P 2=\frac{21}{49} \times 100 \%=42.85 \%$. In the last test, all of the students got the point 75 and up. So, the percentage of this was $P 3=\frac{49}{49} \times 100 \%=100 \%$.

\section{Research Findings}

After analyzing the data, the finding of this research showed that reciprocal teaching method was able to improve the students' reading comprehension. The data showed that the students score increased in every test. It means that the actions were done successfully. It was supported by the mean of orientation test was 61.79 , cycle I 72.24 and cycle II 81.71.

\section{CONCLUSIONS AND SUGGESTIONS}

\section{Conclusion}


This research finally brought a finding that the score of the students were increasing in each test. The mean of orientation test was 61.79 , cycle I was 72.24 and cycle II was 81.71 .

Based on the result of the data, it can be concluded that reciprocal teaching method significantly improves students' reading ability in narrative text.

\section{Suggestions}

There are some suggestions offered to improve a better skill achievement in reading comprehension. The suggestions are:

a. It is important to the English teacher to use an appropriate strategy in teaching reading such as reciprocal teaching method, for instance reading narrative text.

b. For the students, it is suggested to use reciprocal teaching method because this method trains the students to learn independently with or without teacher and can increase their social interaction with other students especially in their group. This method also can train the students to be able to lead the group and become brave to speak in English. 


\section{REFERENCES}

Carter Ronald and McCarthy Michael. 2006. Cambridge Grammar of English. Cambridge: University Press

Grabe, William and Fredricka L. Stoller. 2002. Teaching and Researching Reading. England: Longman

Kemmis, S \& Mc Taggart, R. 1998. The Action Research Planner ( ${ }^{\text {rd }}$ Ed) in Burns.

Nunan, David. 2003. Practical English Language Teaching. New York: McGraw Hill.

Oczkus. 2003. Using the Reciprocal Teaching Method by Teachers at Jordanian Schools. European Journal of Social Sciences-Volume 15, Number 1

Palinscar, A. S., \& Brown, A. L. 1984. Reciprocal Teaching of ComprehensionFostering and Comprehension-Monitoring Activities. Cognition and Instruction, 1 (2), 117-175.

Palinscar, A. S., \& Brown, A, L. 1986. Interactive Teaching to Promote Independent Learning from Text. The Reading Teacher.

Palinscar, A. S., \& Klenk, L. 1991. Dialogues Promoting Reading Comprehension. In B. Means, C. Chelemer, \& M. S. Knapp (Eds.), Teaching Advanced Skills To At-Risk Students (pp. 112-40). San Fransisco: Jossey-Bass

Pardiyono. 2007. Pasti Bisa! Teaching Genre-Based Writing. Yogyakarta: Andi

Wallace, M. J. 1998. Action Research for Language Teacher. Cambridge: University 